\title{
PENGEMBANGAN BAHAN AJAR DALAM BENTUK BUKU SAKU PADA POKOK BAHASAN ASAM BASA
}

\section{Nova Trisna Wati, Erviyenni, Betty Holiwarni}

Program Studi Pendidikan Kimia, Fakultas Keguruan dan Ilmu Pendidikan Universitas Riau, Kampus Binawidya KM 12,5, Pekanbaru 28293, Riau, Indonesia

\begin{tabular}{l}
\hline \multicolumn{1}{c}{ Informasi Artikel } \\
\hline Sejarah Artikel: \\
Diterima 30 Maret 2019 \\
Disetujui 24 Juli 2019 \\
Dipublikasikan 26 Juli 2019 \\
\\
\hline Keywords: \\
Research and development, \\
ADDIE, \\
Teaching materials, \\
Pocket books \\
\hline
\end{tabular}

\begin{abstract}
Abstrak
Penelitian ini bertujuan untuk mengembangkan bahan ajar dalam bentuk buku saku pada pokok bahasan asam basa yang valid berdasarkan aspek kelayakan isi, kebahasaan, penyajian, kegrafisan dan praktis untuk digunakan peserta didik dalam pembelajaran. Jenis penelitian ini adalah penelitian (Reasarch) dan pengembangan (Development), dengan model pengembangan ADDIE yang meliputi analisis), desain, pengembangan, Implementasi), dan evaluasi. Penelitian ini baru dilakukan sampai tahap pengembangan. Teknik analisis data yang digunakan dalam penelitian adalah statistik deskriptif, yaitu dengan cara menghitung persentase nilai validasi. Data-data yang diperoleh berasal dari validator yang terdiri atas tiga dosen ahli, responden yang terdiri atas empat guru dan 30 peserta didik dari dua SMA yaitu SMAN 3 dan SMAN 5 Pekanbaru. Hasil penelitian menunjukkan bahwa pengembangan bahan ajar dalam bentuk buku saku pada pokok bahasan asam basa kelas XI untuk SMA/MA se-derajat dinyatakan valid memenuhi aspek kelayakan isi, aspek kelayakan kebahasaan, aspek kelayakan sajian dan aspek kelayakan kegrafisan. Skor rata-rata keseluruhan validasi buku saku adalah 91,92\% dengan kategori sangat valid. Hasil uji coba respons guru dan peserta didik terhadap buku saku asam basa berturut-turut adalah $90 \%$ dan $93,57 \%$ dengan kriteria sangat baik sehingga buku saku dinyatakan praktis untuk digunakan peserta didik dalam pembelajaran.
\end{abstract}

\begin{abstract}
This study aims to develop teaching materials in the form of pocket books on valid acid base topics based on the feasibility aspect of content, language, presentation, graphics and practical for students to use in the learning. This type of research is research and development, with the ADDIE development model which includes Analysis, Design, Develop, Implementation and Evaluation. This research was only carried out until the development stage. Data analysis techniques used in the study were descriptive statistics, namely by calculating the percentage value of validation. The data obtained came from the validator consisting of three expert lecturers, respondents who consists of four teachers and 30 students from two high schools namely SMAN 3 and SMAN 5 Pekanbaru. The results showed that the development of teaching materials in the form of pocket books on the subject of class XI acid base for SMA/MA as stated as valid fulfilled the aspects of eligibility content, aspects language feasibility, feasibility aspects of presentation and graphic feasibility aspects. The average score of pocket book validation scores
\end{abstract}


is $91,92 \%$ with very valid categories. The results of the trials of responses of teachers and students to acid base pocket books are $90 \%$ and 93,57\% respectively with very good criteria so the pocket book is declared practical for students to use.

(C) 2019 Universitas Riau

*Alamat korespondensi:

novatrisna27@gmail.com (NTW), holi_warni@yahoo.com (BH)

No. Telf: 085265707445

\section{PENDAHULUAN}

Pembelajaran adalah sebuah proses atau usaha pendidik untuk melaksanakan aktivitas belajar pada peserta didik. Proses pembelajaran melibatkan motivasi belajar peserta didik. Menurut Hamalik, (2005), motivasi dibagi menjadi dua jenis yaitu motivasi intrinsik (faktor dari dalam diri peserta didik) dan motivasi ekstrinsik (faktor dari luar). Motivasi ekstrinsik menjadi pemicu munculnya motivasi intrinsik. Motivasi ekstrinsik berasal dari orang tua, pendidik dan lingkungan belajar peserta didik. Guru sebagai pendidik wajib memperhatikan motivasi ekstrinsik ini di antaranya pemberian penghargaan atau hukuman, strategi pembelajaran, model pembelajaran, dan teknik belajar.

Salah satu mata pelajaran yang ada di Sekolah Menengah Atas (SMA/MA) adalah mata pelajaran kimia. Mata pelajaran kimia merupakan salah satu cabang dari ilmu sains. Salah satu materi yang terdapat dalam pembelajaran kimia adalah materi asam basa. Pada pokok bahasan asam basa masih ditemui salah satu hambatan dalam proses pembelajaran yakni motivasi belajar peserta didik yang masih rendah. Hal ini terlihat dari rendahnya nilai ulangan peserta didik. Untuk menunjang proses pembelajaran peserta didik diberikan buku pegangan dari bantuan dana BOS. Namun peserta didik kurang termotivasi untuk membaca buku karena buku yang digunakan memiliki ukuran yang besar sehingga berat untuk dibawa ke mana-mana dan memiliki uraian baca yang panjang. Jika buku teks yang digunakan sebagai sumber belajar terbatas baik dari segi isi, format penyajian maupun kebahasaan, proses pembelajaran menjadi kurang menarik (Mucharommah et al., 2012).

Sadirman, (2011) menjelaskan bahwa peserta didik perlu diberikan suatu rangsangan agar tumbuh motivasi belajar pada dirinya. Salah satu bentuk rangsangan yang dapat digunakan untuk meningkatkan motivasi belajar peserta didik adalah dengan menggunakan bahan ajar. Oleh karena itu, dibutuhkan pengembangan bahan ajar yang efektif sesuai kondisi lingkungan belajar tersebut. Peneliti mencoba memberikan solusi dengan membuat bahan ajar yang praktis dibawa, tampilannya menarik, materinya lebih mudah dipahami, dan dapat digunakan oleh semua peserta didik sehingga dapat meningkatkan motivasi belajar peserta didik. Bahan ajar yang dikembangkan dalam penelitian ini adalah buku saku. Buku saku menggunakan banyak warna dan animasi yang menarik. Menurut Mucharommah et al., (2012) "otak cenderung menyukai gambar/ilustrasi dan warna dibandingkan tulisan". Buku saku juga dinilai praktis dari segi ukurannya yang kecil. Dengan adanya buku saku ini diharapkan peserta didik menjadi lebih mudah dalam memahami materi asam basa karena peserta didik dapat membaca buku saku kapan saja dan di mana saja. Penelitian Pengembangan Buku Saku pernah dilakukan oleh Salyani, 
(2018) pada materi reaksi reduksi oksidasi (Redoks) di MAN Model Banda Aceh. Hasil penelitian menunjukkan pengembangan buku saku pada materi Redoks layak digunakan oleh guru sebagai bahan ajar di kelas dan juga sebagai sumber belajar dalam kegiatan pembelajaran individual peserta didik di MAN Model Banda Aceh dengan skor rata-rata keseluruhan validasi adalah $94 \%$. Rahmawati et al., (2013) telah mengembangkan buku saku IPA dengan tema bahan kimia dalam kehidupan sehari-hari. Hasil penelitian ini menemukan bahwa hasil belajar siswa mencapai ketuntasan belajar sebesar $85.7 \%$. Di samping itu, baku saku yang dikembangkan sangat baik digunakan sebagai bahan ajar untuk keperluan pembelajaran. Budinigsih et al., (2015) telah mengimplementasikan buku ajar ilmu pengetahuan alam berorientasi literasi sains pada materi energi dan suhu. Penelitian Budiningsih et al., 2015 menggunakan rancangan pengembangan Borg dan Gall. Hasil kajian ini menemukan bahwa buku ajar yang dikembangkan memenuhi kriteria valid dan mudah dipahami oleh siswa.

Berdasarkan uraian yang telah dikemukakan, penulis tertarik untuk mengembangkan bahan ajar yang dituangkan dalam penelitian dengan judul "pengembangan bahan ajar dalam bentuk buku saku pada pokok bahasan asam basa”.

\section{METODE PENELITIAN}

Penelitian pengembangan bahan ajar dalam bentuk buku saku pada pokok bahasan asam basa dilakukan di Fakultas Keguruan dan Ilmu Pendidikan (FKIP) program studi pendidikan kimia. Penelitian ini menggunakan metode penelitian dan pengembangan berdasarkan model ADDIE. Model ADDIE digambarkan dalam lima tahapan utama (menganalisis, merancang, mengembangkan, melaksanakan, dan mengevaluasi). Model pembelajaran berbasis ADDIE ditunjukkan seperti pada Gambar 1.

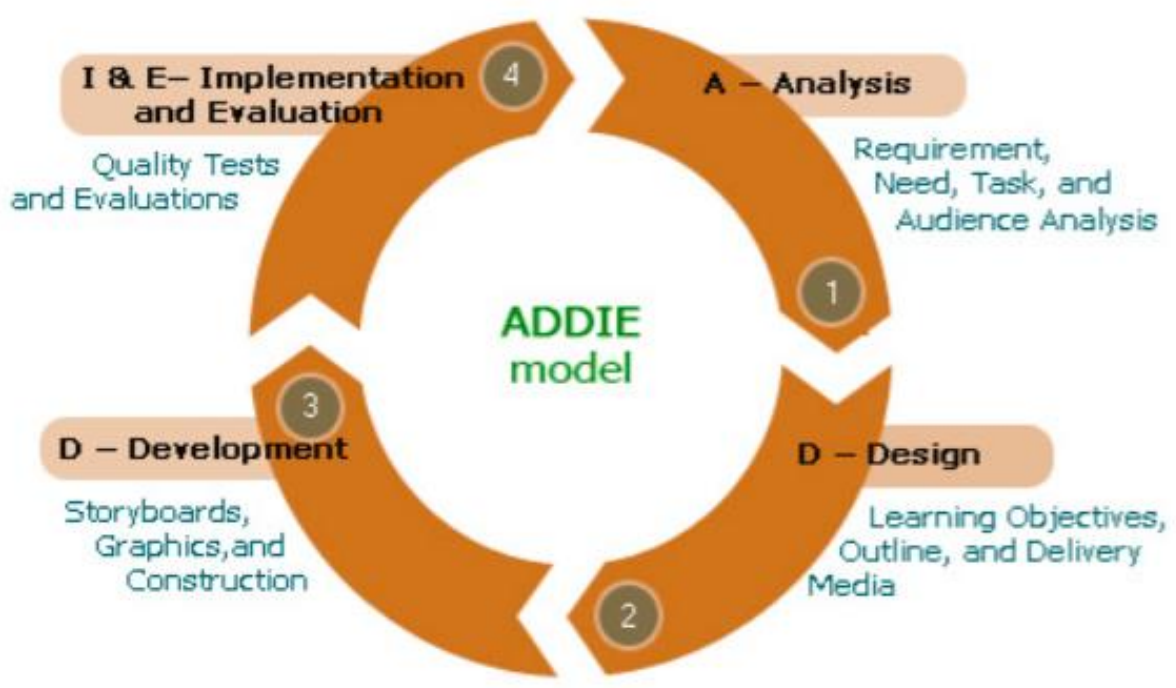

Gambar 1. Desain model pembelajaran ADDIE (Muruganantham, 2015) 
Objek dalam penelitian ini adalah bahan ajar dalam bentuk buku saku pada mata pelajaran kimia pokok bahasan Asam Basa kelas XI. Instrumen yang digunakan adalah silabus pembelajaran kimia pokok bahasan asam basa, lembar validasi, penjabaran validasi, lembar angket respons guru, lembar angket respons peserta didik dan bahan ajar dalam bentuk buku saku. Uji coba produk dilakukan di SMAN 3 dan SMAN 5 Pekanbaru yang terdiri atas 4 guru dan 30 peserta didik sebagai responden. Teknik pengumpulan data pada penelitian, yaitu validasi buku saku oleh tim validator. Data penelitian buku saku dikumpulkan dengan pengisian lembar validasi buku saku oleh validator. Data yang dihasilkan menjadi data yang diolah oleh peneliti sehingga didapatkan hasil analisis data. Teknik analisis data yang digunakan adalah analisis deskriptif, yaitu dengan cara menghitung persentase nilai validasi, formulasinya ditunjukkan pada persamaan 1 .

$$
\text { Persentase }=\frac{\text { skor yang diperoleh }}{\text { skor maksimal }} \times 100 \%
$$

Tingkat kelayakan produk hasil penelitian pengembangan diidentikkan dengan persentase skor. Semakin besar persentase skor hasil analisis data, maka semakin baik tingkat kelayakan produk hasil penelitian pengembangan buku saku. Kriteria kelayakan analisa persentase dapat dilihat pada Tabel 1 .

Tabel 1. Kriteria Kelayakan Analisa Persentase

\begin{tabular}{cc}
\hline Persentase & Keterangan \\
\hline $\mathbf{0 - 2 0}$ & Sangat lemah/tidak valid (diganti) \\
$\mathbf{2 1}-\mathbf{4 0}$ & Lemah/ kurang valid \\
$\mathbf{4 1}-\mathbf{6 0}$ & Cukup/cukup valid \\
$\mathbf{6 1 - 8 0}$ & Kuat/valid \\
$\mathbf{8 1 - 1 0 0}$ & Sangat kuat/sangat valid \\
\hline
\end{tabular}

(Riduwan, 2009)

\section{HASIL DAN PEMBAHASAN}

\subsection{Analisis}

1. Analisis bahan ajar

Analisis terhadap bahan ajar yang digunakan yaitu masih terbatasnya bahan ajar yang dapat memfasilitasi peserta didik dalam memahami materi asam basa. Informasi tersebut diperoleh dari hasil wawancara dengan guru bidang studi kimia, bahwa selama pembelajaran peserta didik difasilitasi dengan buku pegangan dari sekolah. Menurut guru peserta didik masih kurang memahami materi asam basa hal ini terlihat dari rendahnya nilai ulangan harian peserta didik.

2. Analisa peserta didik

Hasil analisis peserta didik menunjukkan bahwa peserta didik kelas XI MIPA SMA/MA memilki rentang usia 16-17 tahun. Berdasarkan teori perkembangan kognitif 
Piaget, maka peserta didik terletak pada tahap operasional formal dan mendekati intelektual yang maksimal.

3. Analisa materi

Hasil analisa materi adalah materi yang disajikan dalam buku saku sesuai tuntutan silabus kurikulum 2013. Materi yang disajikan berdasarkan kompetensi dasar pada silabus kimia 2013 revisi 2017.

\subsection{Desain}

Hasil tahap desain menghasilkan rancangan awal buku saku pada pokok bahasan asam basa dan lembar validasi buku saku. Hasil tahap desain buku saku sebagai berikut:

1) Rancangan awal buku saku

Rancangan buku saku yang dikembangkan sesuai dengan Panduan Pengembangan Bahan Ajar (Depdiknas, 2008) yang meliputi:

a. Judul buku saku

b. Materi pokok buku saku

c. Latihan

d. Penilaian

2) Pembuatan lembar validasi beserta rubrik validasi, dan lembar angket respon pengguna

\subsection{Pengembangan}

\section{a. Aspek kelayakan isi}

Aspek kelayakan isi memiliki 8 butir item yang bertujuan untuk menilai ketepatan konsep kimia pada pokok bahasan asam basa dalam buku saku. Skor rata-rata validasi terhadap aspek kelayakan isi sebagai berikut.

Tabel 2. Penilaian dari validator pada aspek kelayakan isi

\begin{tabular}{|c|c|c|}
\hline No. & Komponen Penilaian & $\begin{array}{l}\text { Persentase } \\
\quad(\%)\end{array}$ \\
\hline 1 & Kesesuaian buku saku dengan Kompetensi Dasar & 100 \\
\hline 2 & Kesesuaian buku saku dengan kebutuhan peserta didik & 100 \\
\hline 3 & Kesesuaian buku saku dengan substansi materi asam basa & 100 \\
\hline 4 & $\begin{array}{l}\text { Buku saku dapat mengarahkan peserta didik untuk membangun } \\
\text { konsep }\end{array}$ & 92 \\
\hline 5 & Manfaat buku saku untuk penambahan wawasan pengetahuan & 83 \\
\hline 6 & $\begin{array}{l}\text { Kesesuaian buku saku dengan nilai moral. Informasi dan kegiatan } \\
\text { yang disajikan dapat meningkatkan keyakinan beragama, } \\
\text { kesopanan, saling menghargai, bertanggung jawab }\end{array}$ & 75 \\
\hline 7 & $\begin{array}{l}\text { Buku saku memiliki kegiatan yang memungkinkan peserta didik } \\
\text { untuk aktif (bertanya dan mengemukakan pendapat) dalam } \\
\text { kegiatan pembelajaran }\end{array}$ & 75 \\
\hline 8 & $\begin{array}{l}\text { Pertanyaan-pertanyaan dalam buku saku membantu mengurutkan } \\
\text { materi asam basa dari yang sederhana ke kompleks }\end{array}$ & 92 \\
\hline
\end{tabular}


Skor rata-rata penilaian tim validator pada aspek kelayakan isi adalah 86,92\% dengan kategori sangat valid. Tabel 2 Menunjukkan bahwa terdapat 3 dari 8 komponen yang mendapat nilai $100 \%$, yaitu komponen 1, 2, dan 3. Menurut penilaian validator, buku saku yang dikembangkan sesuai dengan KD dan IPK pada pokok bahasan asam basa. Materi yang disajikan dalam buku saku jelas dan singkat sehingga dapat memenuhi kebutuhan belajar konsep asam basa dengan baik. Menurut Endang, (2008) kelayakan isi bahan ajar sebagai pedoman bagi peserta didik yang mengarahkan aktivitasnya dan substansi yang harus dipelajari agar tercapai hasil yang diharapkan.

Kemudian komponen 4 dan 8 mendapat nilai 92\%. Validator menilai ada beberapa bagian pada buku saku yang cenderung untuk memberikan konsep secara langsung kepada peserta didik. Pertanyaan yang disajikan secara umum sudah mengurutkan materi asam basa dari yang sederhana ke kompleks, namun ada beberapa pertanyaan pada bagian evaluasi yang kurang berurutan. Misalnya pada bagian pengelompokan senyawa. Sebaiknya sebelum peserta didik mengelompokkan senyawa ke dalam asam dan basa terlebih dahulu peserta didik harus tahu konsep asam dan basa menurut para ahli sehingga bisa mengelompokkan senyawa ke dalam asam dan basa.

Selanjutnya pada komponen 5 mendapat nilai 83\%. Validator menilai bahwa materi yang disajikan dalam buku saku kurang dapat menambah wawasan pengetahuan peserta didik terhadap materi asam basa, karena materi disajikan hampir sama dengan materi yang ada di buku teks pelajaran kimia. Sedangkan, pada komponen 6 dan 7 mendapat nilai $75 \%$. Validator menilai kandungan dalam buku saku kurang menggambarkan nilai moral yang dapat menambah wawasan peserta didik. Validator juga menilai kegiatan yang terdapat dalam buku saku cenderung membuat peserta didik untuk belajar satu arah.

\section{b. Aspek kelayakan kebahasaan}

Aspek kelayakan kebahasaan memiliki 5 komponen penilaian yang bertujuan untuk tingkat keterbacaan atau penggunaan bahasa. Skor validasi terhadap aspek kelayakan kebahasaan diringkaskan dalam Tabel 3.

Tabel 3. Penilaian dari validator pada aspek kelayakan kebahasaan

\begin{tabular}{llc}
\hline No & \multicolumn{1}{c}{ Komponen Penilaian } & $\begin{array}{c}\text { Persentase } \\
(\%)\end{array}$ \\
\hline 1 & Buku saku dapat dibaca dengan baik & 100 \\
2 & Buku saku memiliki informasi yang jelas & 100 \\
3 & Kesesuaian buku saku dengan kaidah Bahasa Indonesia yang & 92 \\
& baku & 92 \\
4 & Buku saku menggunakan kalimat yang efektif dan efisien & 100 \\
5 & $\begin{array}{l}\text { Buku saku menggunakan bahasa sesuai dengan tingkat } \\
\text { kemampuan peserta didik }\end{array}$ & $\mathbf{9 6 , 8 0}$ \\
\hline
\end{tabular}


Validasi aspek kelayakan kebahasaan memiliki 5 komponen penilaian yang bertujuan untuk menilai tingkat keterbacaan atau penggunaan bahasa pada buku saku. Skor rata-rata penilaian tim validator pada aspek kelayakan kebahasaan adalah 96,80 \% dengan kategori sangat valid. Validator menilai bahasa yang digunakan dalam buku saku disesuaikan dengan tingkat perkembangan peserta didik, bersifat komunikatif sehingga dapat memudahkan peserta didik untuk memahami informasi yang disampaikan. Menurut Depdiknas (2008) buku yang baik adalah buku yang ditulis dengan menggunakan bahasa yang baik dan mudah dimengerti, disajikan secara menarik dilengkapi dengan gambar dan keterangan-keterangannya.

\section{c. Aspek kelayakan penyajian}

Aspek kelayakan penyajian memiliki tiga komponen yang bertujuan untuk menilai kualitas penyajian pada buku saku. Skor rata-rata validasi terhadap aspek kelayakan penyajian dapat dilihat pada Tabel 4.

Tabel 4. Penilaian dari validator pada aspek kelayakan sajian

\begin{tabular}{llc}
\hline No & \multicolumn{1}{c}{ Komponen Penilaian } & $\begin{array}{c}\text { Persentase } \\
(\mathbf{\%})\end{array}$ \\
\hline 1 & $\begin{array}{l}\text { Buku saku memiliki struktur yang lengkap (Judul, kata } \\
\text { pengantar, karakteristik buku, daftar isi, kompetensi yang akan } \\
\text { dicapai, peta konsep, materi pokok, informasi pendukung, tugas- }\end{array}$ & 100 \\
& $\begin{array}{l}\text { tugas dan langkah-langkah kerja) } \\
2\end{array}$ & $\begin{array}{l}\text { Buku saku sudah memiliki sistematika yang runut } \\
\text { Buku saku dapat memotivasi peserta didik dalam belajar dan } \\
\text { memecahkan masalah }\end{array}$ \\
\hline & \multicolumn{1}{c}{ Persentase (\%) Skor } & 92 \\
\hline
\end{tabular}

Skor rata-rata penilaian tim validator pada aspek kelayakan penyajian adalah 91,66\% dengan kategori sangat valid. Tabel 4 menunjukkan bahwa terdapat 2 dari 3 komponen yang mendapatkan nilai $100 \%$. Menurut validator, tujuan pembelajaran di dalam buku saku sudah jelas sehingga dapat memudahkan peserta didik untuk mempelajari keseluruhan isi buku saku. Struktur buku saku yang disajikan sudah lengkap, yakni mulai dari kata pengantar, karakteristik buku, kompetensi yang akan dicapai, daftar isi, peta konsep, materi pokok, informasi pendukung, latihan, rangkuman, refleksi diri, evaluasi, glosarium, daftar pustaka hingga kunci jawaban yang disusun secara berurutan. Hal ini sesuai dengan Depdiknas (2008) dalam sebuah buku setidaknya mengandung judul, materi pokok, latihan serta penilaian.

Komponen pernyataan nomor 3 mendapat persentase yang paling rendah daripada komponen lainnya pada aspek kelayakan penyajian, yakni dengan persentase $92 \%$. Validator menilai secara umum buku saku sudah memotivasi peserta didik dalam menyelesaikan suatu masalah hanya saja pengambilan background harus disesuaikan karena kualitas warna pada buku saku ikut mempengaruhi minat peserta didik untuk membaca pada buku saku. 


\section{d. Aspek kelayakan kegrafisan}

Aspek kelayakan kegrafisan memiliki komponen yang bertujuan untuk menilai ketepatan tata letak (layout), tulisan, gambar/foto, dan desain buku saku asam basa. Nilai rata-rata validasi terhadap aspek kegrafisan dapat ditunjukkan pada Tabel 5.

Tabel 5. Penilaian dari validator pada aspek kelayakan kegrafisan

\begin{tabular}{llc}
\hline No. & \multicolumn{1}{c}{ Komponen Penilaian } & $\begin{array}{c}\text { Persentase } \\
(\boldsymbol{\%})\end{array}$ \\
\hline $\mathbf{1}$ & $\begin{array}{l}\text { Buku saku menggunakan jenis dan ukuran huruf yang baik dan } \\
\text { menarik }\end{array}$ & 83 \\
$\mathbf{2}$ & $\begin{array}{l}\text { Buku saku memiliki layout/tata letak yang menarik } \\
\mathbf{3}\end{array}$ & $\begin{array}{l}\text { Buku saku memiliki ilustrasi/gambar/foto yang baik dan } \\
\text { berhubungan dengan konsep }\end{array}$ \\
$\mathbf{4}$ & Buku saku memiliki desain tampilan yang menarik & 92 \\
\hline & & 92 \\
\hline
\end{tabular}

Skor rata-rata penilaian tim validator pada aspek kelayakan kegrafisan adalah $89,58 \%$ dengan kategori sangat valid. Tabel 5 menunjukkan bahwa 3 dari 4 komponen yang mendapatkan nilai 92\%. Menurut validator secara umum buku saku memiliki penempatan tata letak (layout) yang menarik, tetapi masih ada beberapa bagian yang memiliki tata letak yang kurang rapi sehingga perlu diperbaiki sehingga tampilan buku saku menjadi rapi dan menarik. Beberapa gambar/ilustrasi/foto yang dapat menyebabkan kemungkinan terjadinya miskonsepsi pada peserta didik diganti dengan gambar yang lebih jelas. Secara umum desain buku saku sudah menarik namun penggunaan background yang mencolok harus diganti dengan background dengan warna yang soft agar peserta didik merasa nyaman saat membaca buku saku. Penggunaan warna pada buku saku selaras dengan pendapat Azhar Arsyad (2002), beberapa cara yang dapat digunakan untuk menarik perhatian pada media berbasis teks adalah warna, huruf dan kotak. Warna dapat menarik perhatian pembaca huruf yang dicetak tebal atau dicetak miring memberikan penekanan pada kata-kata kunci atau judul.

Tabel 6. Skor Rata-rata Penilaian Keempat Aspek Kelayakan Buku Saku

\begin{tabular}{llcl}
\hline No & \multicolumn{1}{c}{ Aspek yang dinilai } & $\begin{array}{c}\text { Skor Rata- rata } \\
\text { Validasi }(\boldsymbol{\%})\end{array}$ & Keterangan \\
\hline $\mathbf{1}$ & Aspek kelayakan isi & 89,62 & Sangat valid \\
$\mathbf{2}$ & Aspek kelayakan kebahasaan & 96,80 & Sangat valid \\
$\mathbf{3}$ & Aspek kelayakan penyajian & 91,66 & Sangat valid \\
$\mathbf{4}$ & Aspek kelayakan kegrafisan & 89,58 & Sangat valid \\
\hline Skor Rata - Rata Keseluruhan Validasi & 91,92 & Sangat valid \\
\hline
\end{tabular}


Komponen pertama mendapatkan nilai $83 \%$. Menurut validator, ukuran huruf yang digunakan masih kecil sehingga harus diperbesar lagi agar buku saku dapat dibaca peserta didik untuk mempelajari isi buku saku. Hasil rekap skor rata-rata penilaian buku saku dari validator dapat dilihat pada Tabel 6. Berdasarkan Tabel 6 nilai rata-rata setiap aspek kelayakan yang meliputi isi, kebahasaan, penyajian dan kegrafisan diperoleh nilai dalam reng 89,58 - 96,80\%. Nilai aspek kelayakan isi, kebahasaan, penyajian dan kegrafisan ditampilkan dalam bentuk diagram ditunjukkan pada Gambar 2.

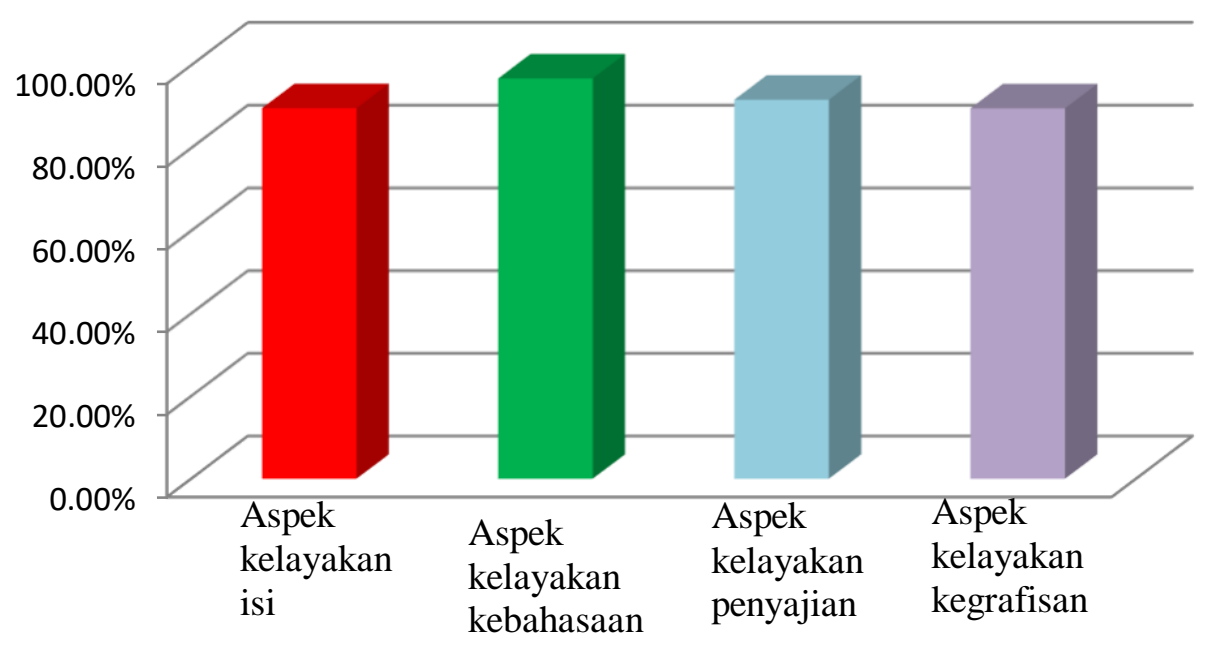

Gambar 2. Grafik Nilai Rata-rata Hasil Validasi Tiap Aspek terhadap Buku Saku Asam Basa.

Skor rata-rata penilaian keseluruhan validasi buku saku asam basa adalah $\mathbf{9 1 , 9 2 \%}$ dengan kategori sangat valid. Sedangkan persentase respons pengguna yaitu guru dan peserta didik berturut-turut adalah $\mathbf{9 0 \%}$ dan 93,57\% dengan kriteria sangat baik. Guru menilai bahwa buku saku asam basa sudah bagus, karena tampilan buku saku yang berwarna membuat tampilan buku saku menjadi menarik sehingga dapat meningkatkan motivasi belajar peserta didik. Materi yang disajikan dalam buku saku mencakup semua materi yang terkandung dalam kompetensi dasar. Menurut guru materi yang disajikan dalam buku saku disusun secara sistematis sehingga memudahkan pemahaman peserta didik terhadap materi asam basa. Guru memberikan masukan untuk latihan setiap sub materi disajikan dalam satu bentuk desain dan warna yang sama misalnya seperti bentuk persegi sehingga untuk bagian latihan akan mencolok dan terlihat perbedaannya dengan bagian-bagian yang lain. Menurut peserta didik buku saku asam basa dapat menambah wawasan pengetahuan terhadap materi asam basa, memudahkan peserta didik untuk melakukan praktikum, karena bahan-bahan yang digunakan dalam praktikum dapat dijumpai dalam kehidupan sehari-hari. Adanya gambar-gambar pendukung dan desain yang menarik di dalam buku saku membuat peserta didik menjadi lebih termotivasi untuk belajar. Hal ini menunjukkan bahwa buku saku asam basa yang dikembangkan oleh peneliti valid dan layak digunakan dalam pembelajaran kimia. 


\section{KESIMPULAN DAN REKOMENDASI}

\subsection{Kesimpulan}

Berdasarkan hasil penelitian dapat disimpulkan bahwa: pengembangan bahan ajar dalam bentuk buku saku pada pokok bahasan asam basa kelas XI untuk SMA/MA sederajat dinyatakan valid memenuhi aspek kelayakan isi, aspek kelayakan kebahasaan, aspek kelayakan sajian dan aspek kelayakan kegrafisan. Skor rata-rata keseluruhan validasi buku saku adalah 91,92\% dengan kategori sangat valid. Hasil uji coba respons guru dan peserta didik terhadap buku saku asam basa berturut-turut adalah $90 \%$ dan 93,57\% dengan kriteria sangat baik.

\subsection{Rekomendasi}

Pengembangan buku saku dikatakan berhasil apabila valid dan reliabel. Sedangkan buku saku yang dikembangkan ini baru melalui tahap validitas untuk menguji kevalidan buku saku dan uji coba terbatas berupa respons peserta didik terhadap buku saku yang dikembangkan peneliti. Oleh karena itu, penulis mengharapkan agar buku saku yang dikembangkan ini dilanjutkan dengan penelitian selanjutnya yaitu pada tahap uji coba produk, revisi produk, dan uji coba lapangan untuk mendapatkan nilai reliabilitasnya agar dapat ditentukan apakah buku saku ini layak digunakan di sekolah secara massal atau tidak.

\section{DAFTAR PUSTAKA}

Azhar Arsyad. 2002. Media Pembelajaran. PT. Rajagrafindo Persada. Jakarta.

Budiningsih, T.Y. Rusilowati, A. Marwoto, P. 2015. Pengembangan buku ajar ipa terpadu berorientasi literasi sains materi energi dan suhu. Journal of Innovative Science Education. 4(2): 3 - 40.

Depdiknas. 2008. Panduan Pengembangan Bahan Ajar. Departemen Pendidikan Nasional Direktorat Jenderal Manajemen Pendidikan Dasar dan Menengah Direktorat Pembinaan Sekolah Menengah Atas. Jakarta.

Endang W. 2008. Kualitas Lembar Kerja Siswa. Makalah Seminar Pelatihan Penyusunan LKS Untuk Guru SMK/MAK pada Kegiatan Pengabdian kepada Masyarakat Jurusan Pendidikan FMIPA Universitas Negeri Yogyakarta. Dalam jaringan http://staffnew.uny.ac.id/upload/131569340/pengabdian/kualitas-lks.pdf (Diakses 15 Oktober 2018).

Hamalik, O. 2005. Proses Belajar Mengajar. PT Bumi Aksara. Jakarta.

Mucharommah S.A, Endang S., Raharjo. 2012. Pengembangan Buku Saku Materi Sistem Ekskresi Manusia di SMA/MA Kelas XI. Jurnal Bioedu, 1(2): 10 - 13.

Muruganantham, G. 2015. Developing of E-content package by using ADDIE model . International Journal of Applied Research. 1(3): 52-54 
Jurnal Pendidikan Kimia Universitas Riau 2019 4(2): 36 - 46

https://ejournal.unri.ac.id/index.php/JPKUR

Rahmawati, N.L. Sudarmin, Pukan, K.K. 2013. Pengembangan buku saku ipa terpadu bilingual dengan tema bahan kimia dalam kehidupan sebagai bahan ajar di MTs. Unnes Science Education Journal. 2(1): 157-164.

Riduwan. 2009. Skala Pengukuran Variabel-Variabel Penelitian. Alfabeta. Bandung.

Salyani, R. 2018. Pengembangan Buku Saku pada Materi Reaksi Reduksi Oksidasi (Redoks) di MAN Model Banda Aceh. Jurnal IPA dan Pembelajaran IPA. 02(01); 7 14.

Sardiman. 2011. Interaksi dan Motivasi Belajar Mengajar. Rajawali Pres. Jakarta. 